\title{
Realigning Value Chain Concept towards Destination Branding: Zimbabwe Tourism Destination Reality
}

\author{
Farai Chigora (Corresponding author) \\ Faculty of Commerce, Catholic University of Zimbabwe, Zimbabwe \\ E-mail: fchigora@yahoo.com Tel: 263-772-886-871 \\ Promise Zvavahera \\ National University of Science and Technology, Zimbabwe \\ E-mail: promisezvavahera59@gmail.com Tel: 263-773-471-703
}

Received: July 31, 2015 Accepted: August 25, 2015 Published: November 9, 2015

doi:10.5296/bmh.v3i2.8544ＵRL: http://dx.doi.org/10.5296/bmh.v3i2.8544

\begin{abstract}
The study analysed the value chain model that was used to analyse the sustainable competitive advantage of manufacturing businesses by Porter in 1985. The processes of the model which are both primary and secondary variables were matched and compared to the tourism destination processes. This was done in order to design a specific value chain model that can be used by a tourism destination so as to improve brand equity. The study therefore analysed Zimbabwe as a tourism destination which needs to improve its brand equity through an effective tourism value chain. The study used a sequential mixed method in order to establish data from respondents. It started with a qualitative design whereby by Zimbabwe tourism destination processes were established through in-depth interviews from various experts in the industry. The identified variables were local people, natural resources and destination marketers. Also the respondents agreed that the secondary factors for a Zimbabwe tourism destination value chain include finance, skilled human resources, infrastructure, sustainable practices and global partnerships. The relationship of Zimbabwe tourism destination variables to Porter's primary value chain activities were identified through a quantitative design using survey questionnaires. The results of the study showed that the inbound logistics is related to local people, operations to natural resources and outbound logistics to destination marketers. The study recommended a value chain model specifically for tourism destinations that comprise of local people, natural resources and destination marketers as the primary activities. An effective mix of the tourism primary factors and
\end{abstract}


secondary factors (finance, infrastructure, skilled human resources, sustainable practices and global partners) will lead to improved brand equity for the Zimbabwe tourism destination.

Keywords: value chain, destination branding, Zimbabwe, branding, tourism destination

\section{Introduction}

Zimbabwe tourism destination brand has suffered from various negative events that have transpired within and outside the country. These events were triggered by socio-economic and political downfalls that labeled the tourism destination as treacherous for tourists (Chibaya, 2013; Ndlovu \& Heath, 2013). The tourism sector has been targeted as one of the economic pillars that can enhance viability of Zimbabwe through the finance it contributes to the Gross Domestic Product and Balance of Payment. According to Lin and Chang (2009) many nations and producers are striving to align with dynamism in comparative advantage and thus are moving into industries that help in increasing their returns. Therefore a wide range of activities have been regarded and grouped as offerings that make up the tourism industry. Some of the activities can bring satisfaction of the tourist in isolation and others need to be supported or combined to complete tourist consumption. Tourism is however a service industry mainly characterised by intangibility of both consumption and its offerings. The tourists can demand a tourism service through their actions (travel bookings, accommodation enquiry and other initiatives) but the supply might not be easily identified because of the intangibility nature of the tourism product. Travel agencies and other tourism businesses have therefore used packages as an effort to tangiblise, promote and ensure maximum satisfaction of the tourist. The same deportment has made it difficult to brand the tourism product. This is because branding has been traditionally common to tangible products that can be easily and visibly labeled and packaged. Porter (1985) has introduced a value chain model to ensure a sustainable competitive advantage in industries. This is a combination of activities required to transform basic raw materials to consumable products. The effect of a well crafted value chain has been discovered as profitability measured by the increase in margins from these processes. According to Armstrong and Sambamurthy (1999) the value chain has gained its popularity as a tool that has resulted in businesses safeguarding their position in a competitive market. It has been reckoned as an alignment of activities from conception to production and final delivery of a product or service to customers (Kaplinsky \& Morris, 2002). Also from a complete product perspective, the value chain has been accepted as a supply chain (Hobbs et al., 2000). This is because it completes the supply of goods with minimum defects. The value chain model has be designed and presented by Porter (1985) as shown in Figure 1 below. 


\section{Macrothink}

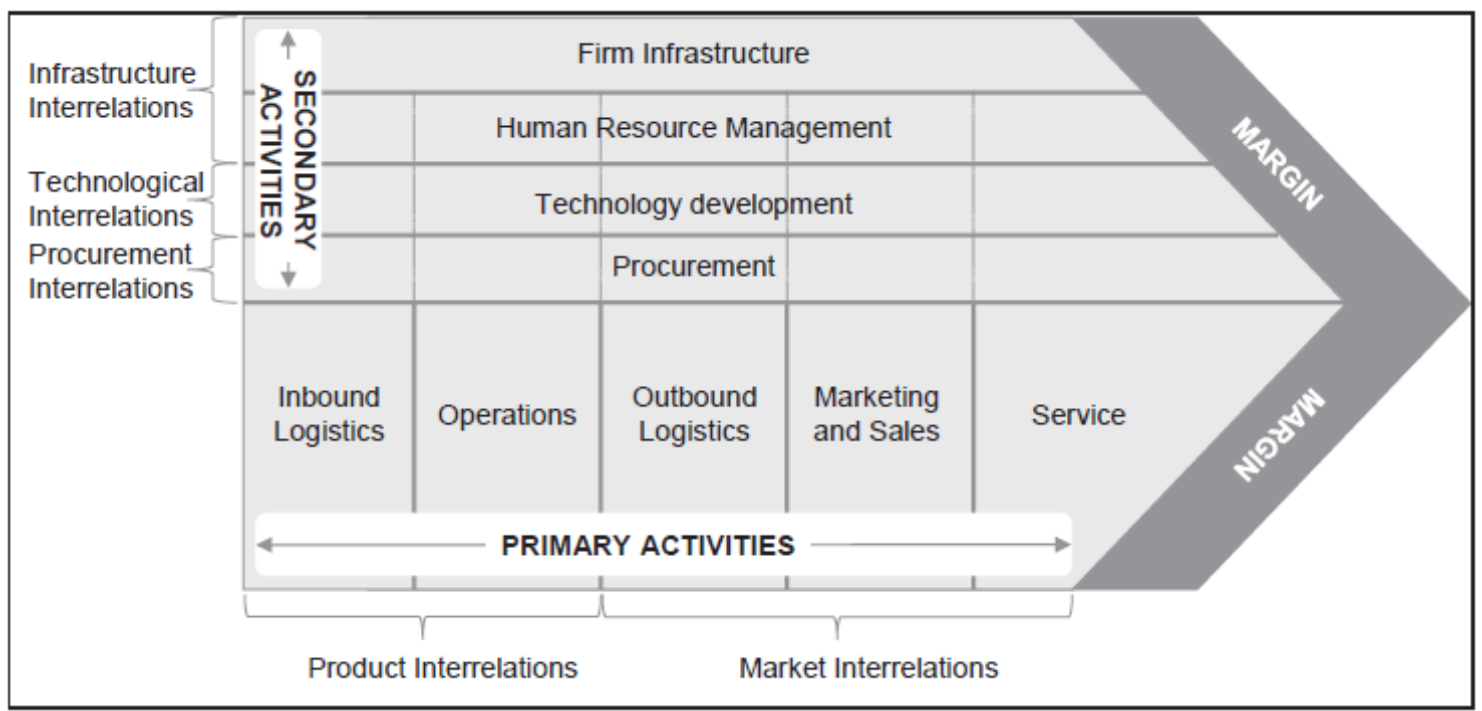

Figure 1. Porter's value chain model for sustainable competitive advantage

Source: Porter (1985).

The value chain model is made up of two variables which are primary activities and secondary activities. The primary activities have been established as inbound logistics, operations, outbound logistics, marketing and sales and services. These are supported by firm infrastructure, human resources management, technology development and procurement. As denoted by Porter (1985), a blend of these primary and secondary activities leads to improved margin or profitability. The tourism industry as a service sector does not have a well conceptualized branding value chain model. This calls for an investigation into the most dominant tourism variables that can be used to craft a value chain model for tourism destinations. The study focus was on the variables that could be used to establish a value chain model particularly for Zimbabwe tourism destination so as to improve its brand equity.

\section{Problem Statement}

There is no clear line of processes that can help improve the Zimbabwe tourism destination brand for sustainable competitive advantage. In the manufacturing industry a value chain model was established by Porter in 1985 as a means to enhance sustainable competitive advantage. The value chain a concept is however limited in practice for the service industries particularly the tourism industry. The study therefore investigated the value chain processes that can be used to improve tourism destination branding with reference to Zimbabwe.

\section{Literature Review}

Kaplinsky (2001) denoted that the value chain analysis is centered on ensuring a smooth run of activities in production from the input stage of production to manufacturing and the end product or service. It is made up of primary and secondary factors that are used to gain competitive advantage (Porter, 1985; Morden, 2007). Also Giuliani (2005) announced that 
the value chain analysis relies on the actors that are combined to establish a relationship and provide implications on sustainable competitive advantage. Hergert and Morris (1989) revealed that a value chain analysis can be used as a source of sustainable competitive advantage, resolve linkages that are complicated and identifies strategies for value creation. According to Christian (2010) a tourism destination value chain can be viewed as shown in Figure 2 below.

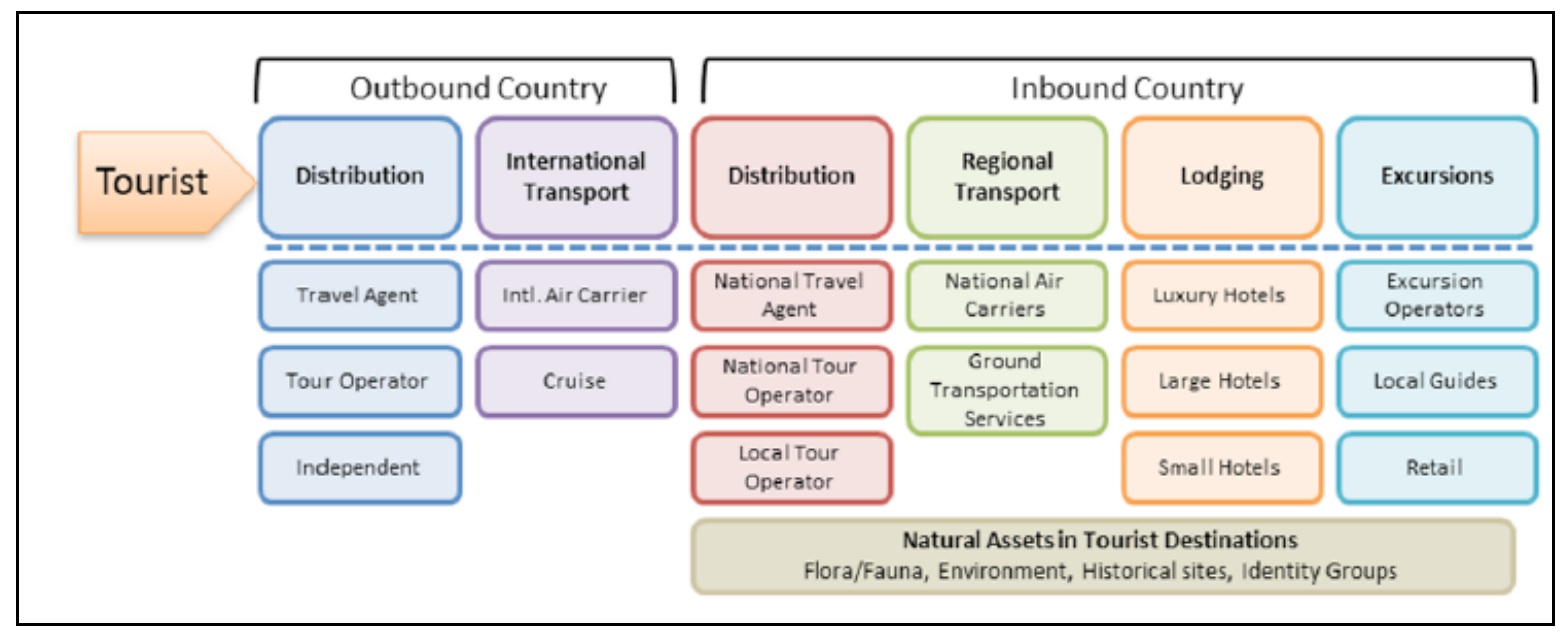

Figure 2. Tourism Value Chain Activities

Source: Christian (2010).

As shown in Figure 2 the tourism value chain comprise of two major variables which are inbound country and outbound country. Inbound country is mainly subjected to the destination offering including natural assets and tourism facilities. Outbound is to do with linking the tourism destination with the outside world through various distribution agents and international transport. The tourism industry can maximise on the linkages that are enhanced by value chains as denoted by Porter (1985) who published that linkages do not only happen in the organisation but also with suppliers through vertical integrations. Destination branding has evolved as a means to uniquely provide identity for a tourism destination and spreading it to potential tourists through various communications using logos, names, designs, symbols, taglines or a combination of all in line with positive image creation (Harish, 2010). Porter (1985) has established three leadership strategies of which one of them is differentiation which can be done in a tourism destination through branding. A comprehensive appreciation and co-ordination of chain activities will reduce costs as well as risks with accelerated reliability in supply or sales (Gibbon, 2001).This therefore mean that value chain analysis can help in enhancing viability in the Zimbabwe tourism destination by triggering sale effect variables and in this case branding.

\section{Methodology}

The research was based on a sequential mixed method. It combined both qualitative and quantitative approaches sequentially starting with qualitative followed by quantitative. This 


\section{Macrothink}

Business and Management Horizons

ISSN 2326-0297

2015, Vol. 3, No. 2

was a QUAL to QUANT research design. The qualitative design helped in extracting the research variables through in-depth interviews from specialists in the Zimbabwe tourism industry. These variables were further analysed on their relation to value chain stages through survey questionnaires. In-depth interviews were done to 10 directors and managers in the tourism industry. These were selected using purposive judgmental sampling based on their expertise and experience in the tourism industry. The questionnaires were distributed to 86 respondents employed and operating tourism businesses in Zimbabwe. Therefore, the total population for the research was 96 respondents.

\section{Findings and Discussions}

The research used in-depth interviews as qualitative research instruments to retrieve data from various experts and senior managers on the most dominant processes of Zimbabwe tourism destination. These were assessed using survey questionnaires on their relationship to core value chain activities and the results are shown from the statistics in table 1 below.

Table 1. Average mean results of tourism activities relation to core value chain variables

\begin{tabular}{|c|c|c|c|}
\hline Tourism components & Inbound Logistics & Operations & Outbound Logistics \\
\hline & (Average mean) & (Average mean) & (Average mean) \\
\hline 1. Local people & 1.330 & 4.173 & 3.951 \\
\hline 2. Destination marketers & 2.216 & 2.778 & 2.108 \\
\hline 3. Natural resources & 2.108 & 1.997 & 2.610 \\
\hline
\end{tabular}

Note. The average mean are in a range of 1-5 (1= Strongly Agree; 5=Strongly Disagree).

Source: Research Survey (2015).

The results in table 1 above shows the value chain relationships as follows

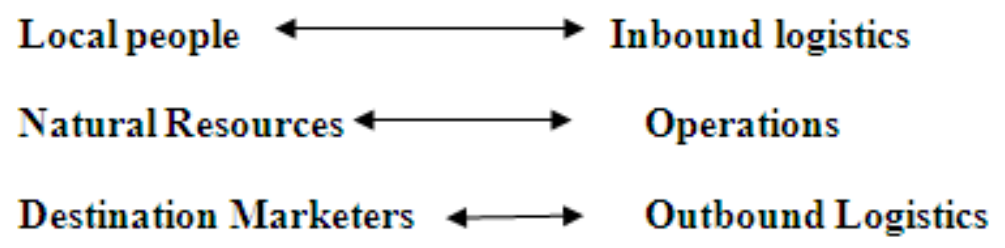




\subsection{Inbound Logistics}

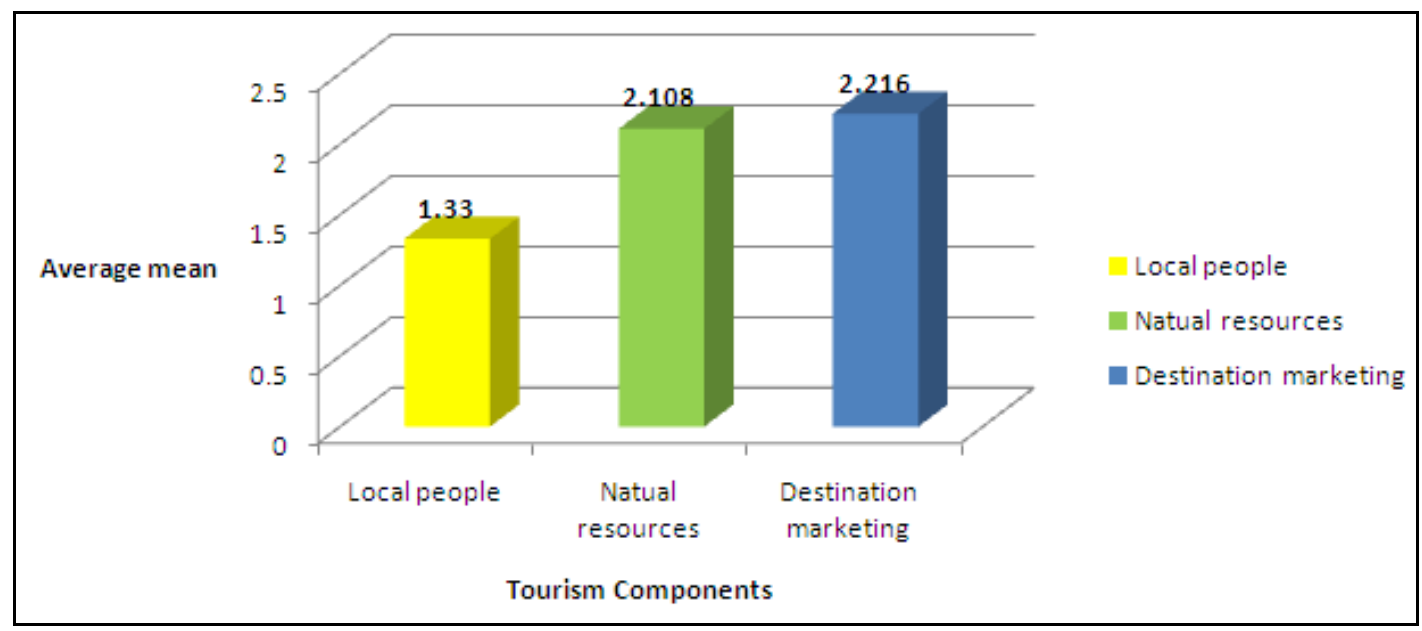

Figure 3. Inbound logistics in relation to tourism activities

Note. The average mean are in a range of 1-5 (1= Strongly Agree; $5=$ Strongly Disagree).

Source: Research Survey (2015).

The results in Figure 3 above shows that there is a strong relationship between local people and the inbound logistics of the value chain process. This is reflected by presented lowest statistical average mean which is equal to 1.33. This is the first stage in the value chain process as alluded by Porter (1985) is known as the inbound logistics. This is a point in production whereby inputs or raw materials are taken into the manufacturing process (Morden, 2009). The results of the study suggested that the local people are related to the inbound logistics of the value chain process. In the production value chain at the inbound stage there is the presence of raw materials or inputs which are introduced into production for further processing into finished products. A destination or country is known because of the existence of people. People make the most dominant factor of production in the tourism industry since it is labour intensive. Therefore, there should be a balance of skills so as to improve customer service. Also communities around touristic areas should be encouraged to by-in the tourism campaign through community trusts and education. This emanates from their role in receiving the tourists as when they first arrive in a tourism destination. The local people can be regarded as both those residing in a tourism destination and those working in the industry. They have great influence that can either encourage or discourage tourism consumption. Their attitude, expressions and other behaviours determines their level of hospitality. A destination that is perceived to be highly hospitable will receive more tourist visit as compared to one that is not. The results therefore reflect the importance of local people in a tourism destination such that they should be an area of focus in order to improve Zimbabwe tourism destination branding. 


\subsection{Operations}

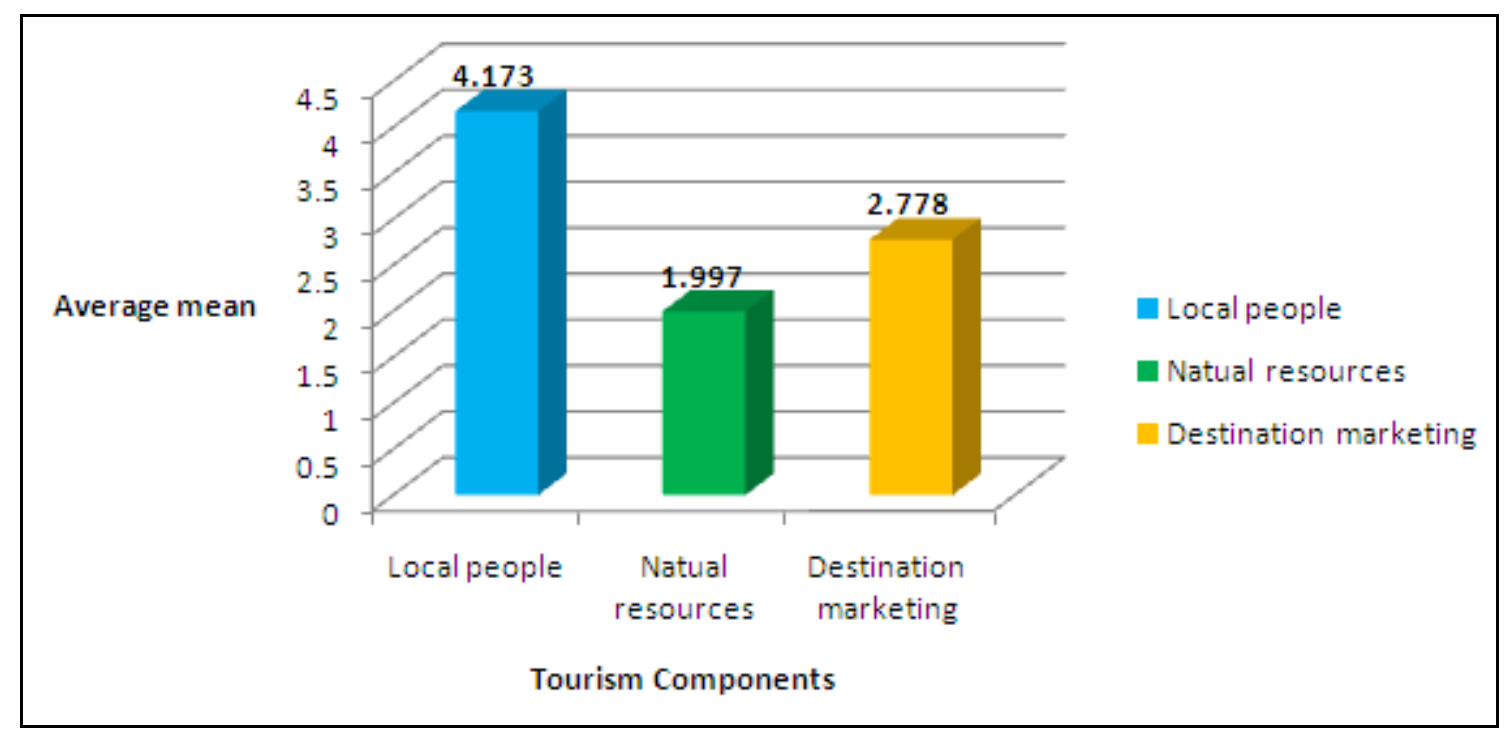

Figure 4. Operations in relation to tourism activities

Note. The average mean are in a range of 1-5 (1= Strongly Agree; 5=Strongly Disagree).

Source: Research Survey (2015).

Figure 4 shows statistical relationship between operations value chain activity and Zimbabwe tourism destination variables. The results reveal that there is a strong relationship between natural resources and operations. This is reflected by a lowest average mean of 1.997 showing that natural resources in a tourism destination are more inclined to the operations stage in a product value chain system. Natural resources in a tourism destination carry the major attractions that are regarded as unique by the tourists. This is because all tourist businesses and activities are done on the natural resources that are unique from one destination to another. These can be seen in a wide range in the form of flora and fauna together with their inhabitants. Land can be regarded as a natural resource upon which tourism businesses like hotels and lodges are built. Also land forms the habitant for all attractive eco-biodiversity such as animals and plants. The three main sectors of the tourism industry (accommodation travel and resorts) are based on natural resources and that is where operations of the tourism business are done. According to Porter (1985) the operations stage is responsible for converting raw materials into products. This aligns to natural resources in a tourism destination as they are processed and designed to attract tourists at this stage. Tourism products such as mountains and rivers are structured in order to provide accessibility for tourists as they walk and stay around them to get scenic and adventure satisfaction. At this stage roads are built, accommodation, bridges and other amenities. Authorities also play a strong role as they put laws and regulations for sustainable resource management. These factors have a strong bearing in branding a tourism destination as their well-being trigger identity and prime positioning of the destination in the global tourism market. 


\subsection{Outbound Logistics}

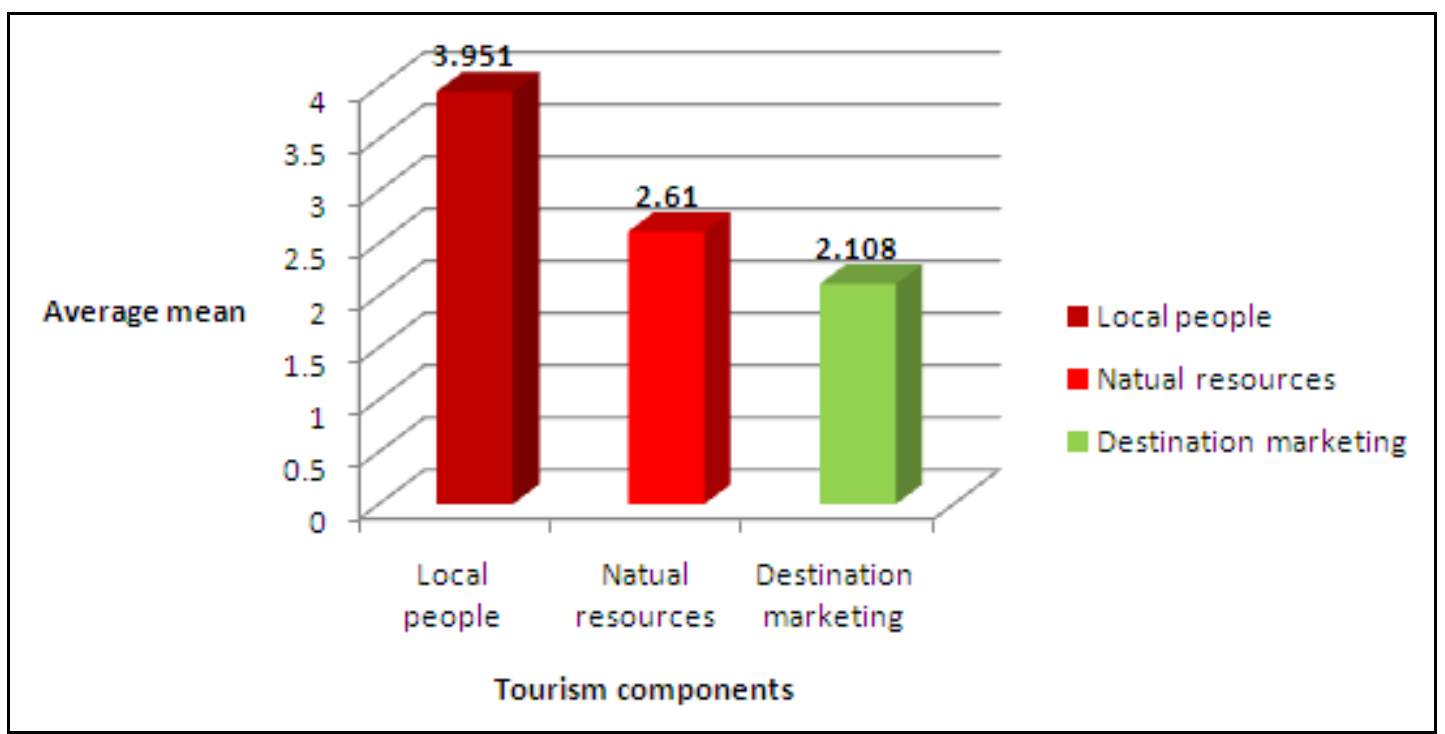

Figure 5. Outbound logistics in relation to tourism activities

Note. The average mean are in a range of 1-5 (1= Strongly Agree; $5=$ Strongly Disagree).

Source: Research Survey (2015).

The statistics in Figure 5 reflects the relationship between the outbound logistics and Zimbabwe tourism destination variables. Destination marketing has the relatively lowest average mean of 2.108 meaning that it is closer to outbound logistics. The respondents agreed that there is a perfect relationship between the outbound logistics and destination marketing. Unlike the value chain of general products, tourism offerings are sold through publicity and promotion that is done to the world. It takes the informed and well crafted marketing skills to improve sales of a tourism destination. Outbound logistics has been considered by Porter (1985) as a stage where products are distributed to customers through various channels. In a tourism destination, it takes the efforts of experienced marketers to lure the hearts and minds of tourists to visit their natural attractions. Zimbabwe Tourism Authority (ZTA) is the main Destination Marketing Organisation (DMO) in the country responsible for all national tourism showcasing activities. It is the one that formulates and implement the branding of Zimbabwe tourism destination. Resources and investment should be effectively allocated to Zimbabwe tourism destination marketers for them to carry out lasting marketing campaigns. It is when the people and natural resources of the country are well marketed that the destination achieves high brand equity.

\section{Recommendations}

Zimbabwe tourism destination authorities should provide training to interact and manage tourists for local communities. This is because these are the people on the ground who deals direct with tourists the moment they get into a tourism destination. People contribute more to the first moment of truth to the tourists. Their attitude, reception and hospitality ignite or 


\section{Al Macrothink}

Business and Management Horizons

ISSN 2326-0297

2015, Vol. 3, No. 2

destroy the need to be in a destination for some time. Even with adequate awareness on the importance of human capital for tourism destinations, several developing countries are still struggling to improve human capital skills due to weak systems in education and training facilities (Liu \& Wall, 2005).This destroys the effort to brand a tourism destination since its brand survival is based on the ability to welcome visitors by the local people.

Infrastructure development is a major determinant of the attractiveness in a tourism destination. Both man-made and natural structures need to be upgraded so as to meet global modern tourists' expectations. This includes building, roads and other amenities that make the destination comfortable and accessible.

Destination marketers provide a completeness of the tourism destination's value chain. Financial budget should be increased for tourism destination marketers. This is because they have the supremacy to integrate all tourism activities towards identity which will position Zimbabwe as a prime tourism destination.

There is a need to consider human skill development in all sectors of the Zimbabwe's tourism industry. This is because the comprehensive integration and multi-player involvement of various stakeholders call for personal innovation and creativity in order to follow a common bandwagon.

Sustainable practices will help in maintaining originality and uniqueness of natural resources in Zimbabwe. This will deter such issues as deforestation of parks, over carrying capacity and extinct of natural resources. Ultimately Zimbabwe tourism destination brand will be regarded as one that will last from one generation to another thus enhancing its global identity.

Global partners are crucial as they provide collaborations in various promotional and developmental issues. Showcasing of the Zimbabwe's tourism offerings at expos, carnivals and indabas can strengthen the tourism destination's value chain towards high brand equity.

Therefore the research recommended a new destination branding value chain model as shown in Figure 6 below.

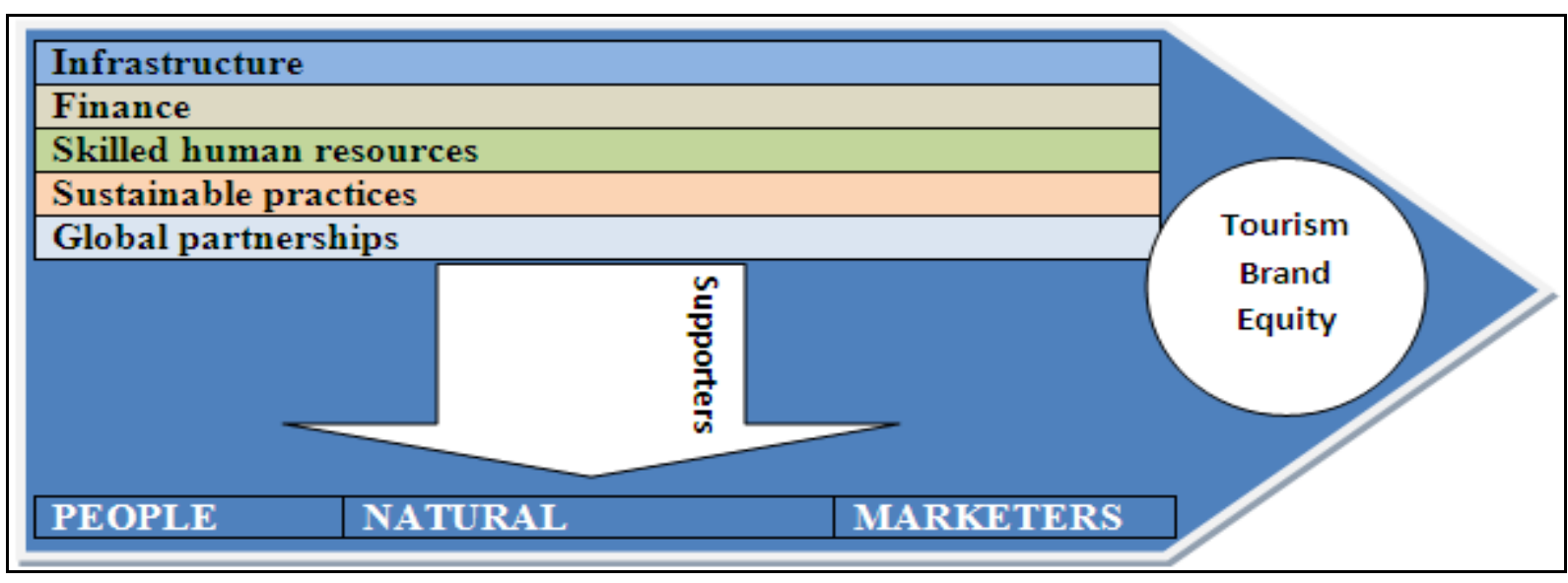

Figure 6. Tourism destination branding value chain model

Source: Research Design (2015). 


\section{Conclusion}

The primary value chain factors of a tourism destination are premised on people, natural resources and tourism destination marketers. These core factors are supported by infrastructure, finance, skilled human resources, sustainable practices and global partnerships. A fusion of both primary and supporting factors will help in improving the brand equity of a destination. The brand equity can therefore be measured by the number of tourist inflows into the country and revenues received from selling of tourism services and products. Zimbabwe tourism destination's value chain needs to be upgraded on the quality of available infrastructure such as hotels and parks. Also there is a need to improve in educating the local people on the benefits of tourism to their communities and the country. This can promote a holistic positive contribution to the tourism brand performance.

\section{References}

Armstrong, C. P., \& Sambamurthy, V. (1999). Information technology assimilation in firms: The influence of senior leadership and IT infrastructures. Information Systems Research, 10(4), 304-327. http://dx.doi.org/10.1287/isre.10.4.304

Chibaya, T. (2013). From 'Zimbabwe Africa’s Paradise to Zimbabwe A World of Wonders': Benefits and Challenges of Rebranding Zimbabwe as A Tourist Destination. Developing Country Studies, 13(5), 84-91.

Christian, M. (2010). Tourism Scoping Paper. Paper prepared for the Capturing the Gains research network. United Kingdom Department of International Development (DFID) supported research project.

Gibbon, P. (2001). Upgrading Primary Production: A Global Commodity Chain Approach. World Development, 29(2), 345-363. http://dx.doi.org/10.1016/S0305-750X(00)00093-0

Giuliani, E., Pietrobelli, C., \& Rabelloti, R. (2005). Upgrading in Global Value Chains: Lessons from Latin American Clusters. World Development, 33(4), 549-573. http://dx.doi.org/10.1016/j.worlddev.2005.01.002

Harish, R., (2010). Brand architecture in tourism branding: the way forward for India. Journal of Indian Business Research, 2(3), 153-165. http://dx.doi.org/10.1108/17554191011069442

Hobbs, J., Cooney, A., \& Fulton, M. (2000). Value chains in the agri-food sector. What are they? How do they work? Are they for me? Department of Agricultural Economics, University of Saskatchewan.

Kaplinsky, R. (2001). Learning networks in the South African auto components industry. Innovation News.

Kaplinsky, R., \& Morris, M. (2002). A handbook for value chain research. International Development Research Centre (IDRC). [Online] Available: http://www.globalvaluechains.org/docs/VchNov01.pdf 


\section{Macrothink}

Business and Management Horizons

ISSN 2326-0297 2015, Vol. 3, No. 2

Lin, J., \& Chang, H. J. (2009). Should Industrial Policy in Developing Countries Conform to Comparative Advantage or Defy it? A Debate Between Justin Lin and Ha Joon Chang. Development Policy Review, 483-502. http://dx.doi.org/10.1111/j.1467-7679.2009.00456.x

Liu, A., \& Wall, G. (2005). Human Resources Development in China. Annals of Tourism Research, 32(3), 689-710. http://dx.doi.org/10.1016/j.annals.2004.10.011

Morden, T. (2007). Principles of Strategic Management (3rd ed.). Bodmin, Cornwall: MPG Books Ltd.

Ndlovu, J., \& Heath, E. (2013). Re-branding of Zimbabwe to enhance sustainable tourism development: Panacea or Villain. Academic Journals, 1(12), 947-955.

Porter, M. E. (1985). Competitive Advantage: Creating Sustainable Performance. New York: Free Press.

\section{Copyright Disclaimer}

Copyright for this article is retained by the author(s), with first publication rights granted to the journal.

This is an open-access article distributed under the terms and conditions of the Creative Commons Attribution license (http://creativecommons.org/licenses/by/3.0/). 